\title{
Relationship between concentrations of microbiological agents in the air of agricultural settings and occurrence of work-related symptoms in exposed persons
}

\author{
Barbara Mackiewicz'1, Czesława Skórska², Jacek Dutkiewicz² \\ ${ }^{1}$ Department of Pneumonology, Oncology and Allergology, Medical University, Lublin, Poland \\ 2 Department of Biological Health Hazards and Parasitology, Institute of Rural Health, Lublin, Poland
}

Mackiewicz B, Skórska Cz, Dutkiewicz J. Relationship between concentrations of microbiological agents in the air of agricultural settings and occurrence of work-related symptoms in exposed persons. Ann Agric Environ Med. 2015; 22(3): 473-477. doi: 10.5604/12321966.1167717

\begin{abstract}
For assessment of the dose-response relationship between concentrations of microbial agents in the air of various agricultural settings and occurrence of work-related symptoms in exposed workers, a meta-analysis of the results obtained in 1994-2007 on the territory of eastern Poland was performed. The studies on the airborne concentrations of total culturable microorganisms, mesophilic bacteria, Gram-negative bacteria, thermophilic actinomycetes, fungi, and bacterial endotoxins, as well as on the frequency of work-related respiratory and general symptoms in the exposed workers, were carried out at grain, thyme, valerian, flax, and hop handling on farms, in cow barns, piggeries, horse stables and in a modern hatchery. The airborne concentrations of the total microorganisms were in the range of $9.2-1236.5 \times 10^{3} \mathrm{CFU} / \mathrm{m}^{3}$, of the total mesophilic bacteria $3.5-1225.8 \times 10^{3} \mathrm{CFU} / \mathrm{m}^{3}$, of Gram-negative bacteria $0.0-46.2 \times 10^{3} \mathrm{CFU} / \mathrm{m}^{3}$, of thermophilic actinomycetes $0.0-7.1 \times 10^{3} \mathrm{CFU} / \mathrm{m}^{3}$, of fungi $2.1-77.9 \times 10^{3} \mathrm{CFU} / \mathrm{m}^{3}$, and of bacterial endotoxin $0.00925-429.55 \mu \mathrm{g} / \mathrm{m}^{3}$. The frequency of work-related symptoms ranged between $21.7-63.8 \%$. In a meta-analysis for assessment of the correlations between the log-transformed concentrations of airborne microbial agents and the occurrence of work-related symptoms, the multiple regression test was applied. Statistically significant correlations were found between the occurrence of workrelated symptoms and the concentration of total airborne microorganisms ( $R=0.748555 ; P=0.020317)$, mesophilic bacteria $(R=0.7573 ; P=0.029548)$, Gram-negative bacteria $(R=0.835938 ; P=0.019129)$, and endotoxins $(R=0.705356 ; P=0.03378)$. The correlations between the concentrations of thermophilic actinomycetes and fungi, on one side, and frequency of work-related symptoms on the other, did not attain the threshold of significance ( $P=0.087049$ and $P=0.062963$, respectively). Results of the meta-analysis confirm harmful health effects of the total airborne microorganisms, total airborne mesophilic bacteria, airborne Gram-negative bacteria, and airborne bacterial endotoxin on the occupationally-exposed agricultural workers, and indicate a need for the establishment of internationally recognized occupational exposure limits for these microbial agents.
\end{abstract}

Key words

agricultural settings, bioaerosol, work-related symptoms, relationship, total microorganisms, mesophilic bacteria, Gramnegative bacteria, endotoxins

\section{INTRODUCTION}

In the past 50 years, it has been well documented that microorganisms present in airborne organic dusts produce various harmful substances which may cause work-related specific or unspecific diseases (such as hypersensitivity pneumonitis or organic dust toxic syndrome) in people occupationally-exposed to the inhalation of such dusts. Allergens and endotoxins produced by Gram-negative bacteria, allergens produced by thermophilic actinomycetes and allergens, mycotoxins and glucans produced by fungi are among the best known agents evoking the disorders $[1,2,3$, $4,5,6,7,8,9,10,11]$. Nevertheless, adverse substances may also be produced by other microorganisms, and hence the total microbiota of the air is regarded by many scientists as a potent source of allergens and toxins, and a good indicator of occupational risk $[12,13,14,15]$.

Address for correspondence: Barbara Mackiewicz, Department of Pneumonology, Oncology and Allergology, Medical University, Jaczewskiego 8, 20-090 Lublin, Poland

E-mail: b.mack@wp.pl

Received: 10 February 2015; accepted: 20 May 2015
To-date, there are no internationally recognized occupational exposure limit values defining the allowable concentrations of total microbiota or its specific constituents in the air $[15,16,17,18]$. Various authors have published proposals for such values, concerning the allowable concentrations of total microorganisms in the air (in $\mathrm{CFU} / \mathrm{m}^{3}$ or cells $/ \mathrm{m}^{3}$ ) and/or the concentrations of particular microorganisms (such as total mesophilic bacteria, Gram-negative bacteria, thermophilic actinomycetes or fungi) and/or the substances of microbial origin, such as bacterial endotoxins $[14,19]$. One of the main obstacles in establishing of widely accepted allowable concentrations of microorganisms and their products in the air is the scarcity of observations on the dose-response relationship between quantitative levels of airborne microbial agents, and the occurrence of work-related symptoms and disorders in the exposed occupational populations. Previously, most of the research on this subject has concerned the effects of airborne endotoxin on the respiratory system of occupationallyexposed individuals, whereas much less attention has been paid to the effects of airborne microorganisms, with regard either to the total count or to particular groups, such as 
Gram-negative bacteria, thermophilic actinomycetes or fungi $[8,19,20,21,22]$.

Taking into consideration the need for better understanding of the relationships between the concentrations of airborne microbial agents in occupational facilities and the occurrence of work-related disorders in exposed persons, as well as the importance of such knowledge for establishing of the reliable occupational exposure limit values, the appropriate metaanalysis for various agricultural settings was undertaken, based on the results of studies performed in 1994-2007 by our group from the Department of Pneumonology, Oncology and Allergology of the Medical University and the Institute of Rural Health in Lublin, Poland.

\section{MATERIALS AND METHODS}

During 1994-2007, measurements of the total concentration of airborne culturable microorganisms, mesophilic bacteria, Gram-negative bacteria, thermophilic actinomycetes, fungi, and the concentration of airborne bacterial endotoxins were carried out on grain farms during grain threshing [23], on thyme farms during cleaning thyme herb [24], on valerian farms during the processing of valerian roots [25], on flax farms during scutching (threshing) flax [26], on hop farms during the handling of hops (picking and sorting of hop cones, drying and packing cones) [27], in cow barns [28], piggeries [28], horse stables [28], and in a modern hatchery [29]. Following the aerobiological measurements, the workers of the investigated settings were asked about the occurrence of work-related symptoms when handling grain [30], thyme [31], valerian [32], flax [33], and hops [34], or working in cow barns [35], piggeries [36], horse stables [37], and a modern hatchery [38].

The methods used in afore-mentioned studies have been described in the above-cited publications. Briefly, microorganisms were isolated from the air by the impaction method with a custom-designed particle-sizing slit sampler [39] enabling estimation of both total and respirable fractions of the bioaerosol $[23,24,26,28]$, or by the filtration method, collecting air samples on preweighed glass fibre or polypropylene filters, with the use of commercial one-stage samplers: AP-2A personal sampler $[25,27]$ or AS-50 stationary sampler [29] (TWOMET, Zgierz, Poland). Mesophilic bacteria were isolated on blood agar, Gram-negative bacteria on eosin methylene blue (EMB) agar, thermophilic actinomycetes on half-strength tryptic soya agar and fungi on malt agar. After incubation, colonies were counted, taxonomically identified and the data reported as colony forming units (CFU) per $1 \mathrm{~m}^{3}$ of air. The concentration of total airborne culturable microorganisms was calculated as a sum of the counts of mesophilic bacteria, thermophilic actinomycetes and fungi. Air samples for the determination of bacterial endotoxins were collected on preweighed polyvinyl chloride filters using an one-stage sampler. Concentration of endotoxins in the airborne dust and in the air $\left(\mu \mathrm{g} / \mathrm{m}^{3}\right)$ was determined by the Limulus amoebocyte lysate (LAL) test.

People working in the agricultural settings examined with aerobiological methods were interviewed by the American Thoracic Society Standard Questionnaire (ATS Questionnaire), compiled by Ferris [40] and by the questionnaire developed in the Institute of Rural Health in Lublin for the examination of work-related symptoms caused by organic dusts [41].

Statistical analysis was performed by the multiple regression test for assessment of the correlations between the airborne concentrations of microbial agents and occurrence of workrelated symptoms, using the STATISTICA ${ }^{\mathrm{Tm}}$ ver. 5.0 package (Statsoft $\odot$, Inc., Tulsa, Oklahoma, USA). Log-transformed values of the concentrations of airborne microbial agents were used for analysis. The $\mathrm{P}<0.05$ level was considered significant.

\section{RESULTS}

The results of the meta-analysis are presented in Tables 1-2 and in Figures 1-4. As confirmed by the Shapiro-Wilk test $(\mathrm{P}<0.01)$, the values showing levels of microbial contaminants of the air were not normally distributed, and therefore the log-transformed median values were used for the presentation and for statistical assessment of relationships between the concentrations of particular contamination and the occurrence of work-related symptoms. The concentrations of the total airborne culturable microorganisms were in the range $9.2-1236.5 \times 10^{3} \mathrm{CFU} / \mathrm{m}^{3}$, the total airborne culturable mesophilic bacteria in the range of $3.5-1225.8 \times 10^{3} \mathrm{CFU} / \mathrm{m}^{3}$, airborne culturable Gram-negative bacteria in the range of $0.0-46.2 \times 10^{3} \mathrm{CFU} / \mathrm{m}^{3}$, airborne culturable thermophilic actinomycetes in the range of $0.0-7.1 \times 10^{3} \mathrm{CFU} / \mathrm{m}^{3}$, airborne

Table 1. Comparison of concentrations of airborne microbial agents in agricultural settings with occurrence of work-related symptoms in exposed workers - Part 1

\begin{tabular}{|c|c|c|c|c|c|c|c|}
\hline \multirow[b]{2}{*}{ Setting, working process } & \multicolumn{2}{|c|}{ Total microorganisms } & \multicolumn{2}{|c|}{ Gram-negative bacteria } & \multicolumn{2}{|c|}{ Endotoxins } & \multirow{2}{*}{$\begin{array}{l}\text { Frequency of work- } \\
\text { related symptoms } \\
(\%)\end{array}$} \\
\hline & $\begin{array}{c}\text { Conc. (x) } \\
\text { CFU/m } \mathrm{m}^{3^{\prime}} 10^{3}\end{array}$ & $\log _{10} x$ & $\begin{array}{c}\text { Conc. (x) } \\
\text { CFU/m } \mathrm{m}^{3^{\prime}} 10^{3}\end{array}$ & $\log _{10} x$ & $\begin{array}{l}\text { Conc. (x) } \\
\mu \mathrm{g} / \mathrm{m}^{3}\end{array}$ & $\log _{10} x$ & \\
\hline Thyme farms, cleaning thyme herb & 372.2 & 2.571 & $\mathrm{Nd}$ & $\mathrm{Nd}$ & 429.55 & 2.633 & 63.8 \\
\hline Valerian farms, processing valerian roots & 10.75 & 1.031 & 0.7 & -0.155 & 33.43 & 1.524 & 30.7 \\
\hline Hop farms, handling hop cones & 9.2 & 0.964 & 0.0 & -1.000 & 0.0522 & -2.718 & 21.7 \\
\hline Cow barns & 216.0 & 2.334 & 3.9 & 0.591 & 0.00925 & -3.966 & 22.2 \\
\hline Piggeries & 1236.5 & 3.092 & 15.5 & 1.190 & 31.25 & 1.495 & 58.5 \\
\hline Horse stables & 109.95 & 2.041 & 3.8 & 0.580 & 0.02611 & -2.417 & 51.6 \\
\hline Modern hatchery* & 16.83 & 1.226 & 0.58 & -0.237 & 0.36425 & -1.561 & 25.0 \\
\hline
\end{tabular}

Conc. - median concentration; $\mathrm{Nd}$ - not determined; *fungi not determined 
Table 2. Comparison of concentrations of airborne microbial agents in agricultural settings with occurrence of work-related symptoms in exposed workers - Part 2

\begin{tabular}{|c|c|c|c|c|c|c|c|}
\hline \multirow[b]{2}{*}{ Setting, working process } & \multicolumn{2}{|c|}{ Total mesophilic bacteria } & \multicolumn{2}{|c|}{ Thermophilic actinomycetes } & \multicolumn{2}{|c|}{ Fungi } & \multirow{2}{*}{$\begin{array}{l}\text { Frequency of work- } \\
\text { related symptoms } \\
(\%)\end{array}$} \\
\hline & $\begin{array}{c}\text { Conc. (x) } \\
\text { CFU/m } \mathrm{m}^{3} 10^{3}\end{array}$ & $\log _{10} x$ & $\begin{array}{c}\text { Conc. }(x) \\
\text { CFU/m } \text { m }^{3} 10^{3}\end{array}$ & $\log _{10} x$ & $\begin{array}{c}\text { Conc. (x) } \\
\text { CFU } / \mathrm{m}^{3} 10^{3}\end{array}$ & $\log _{10} x$ & \\
\hline Grain farms, threshing grain & $\mathrm{Nd}$ & $\mathrm{Nd}$ & $\mathrm{Nd}$ & $\mathrm{Nd}$ & $\mathrm{Nd}$ & $\mathrm{Nd}$ & 44.7 \\
\hline Thyme farms, cleaning thyme herb & 281.5 & 2.449 & 7.1 & 0.851 & 77.9 & 1.892 & 63.8 \\
\hline Valerian farms, processing valerian roots & 3.5 & 0.544 & 0.2 & -0.699 & 3.4 & 0.532 & 30.7 \\
\hline Flax farms scutching flax & 255.8 & 2.408 & 0.6 & -0.222 & 41.6 & 1.619 & 62.7 \\
\hline Hop farms, handling hop cones & 5.0 & 0.699 & 0.4 & -0.398 & 2.1 & 0.322 & 21.7 \\
\hline Cow barns & 125.1 & 2.097 & 1.2 & 0.090 & 4.5 & 0.653 & 22.2 \\
\hline Piggeries & 1225.8 & 3.088 & 1.4 & 0.146 & 3.6 & 0.556 & 58.5 \\
\hline Horse stables & 94.6 & 1.976 & 4.6 & 0.663 & 5.4 & 0.732 & 51.6 \\
\hline Modern hatcher. & 16.8 & 1.225 & 0.0 & -1.000 & 0.36425 & N.d. & 25.0 \\
\hline
\end{tabular}

Conc. - median concentration; Nd - not determined

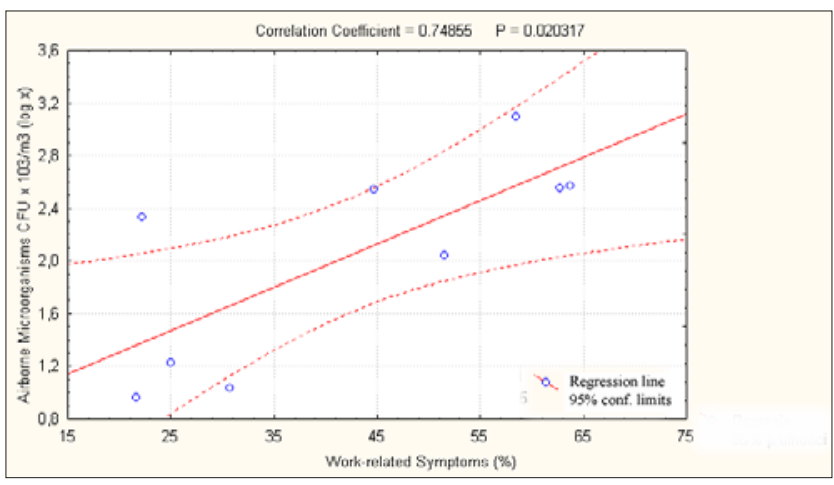

Figure 1. Correlation between concentration of total airborne culturable microorganisms (CFU $\times 10^{3} / \mathrm{m}^{3}, \log _{10} \mathrm{x}$ ) and frequency of work-related symptoms in exposed agricultural workers

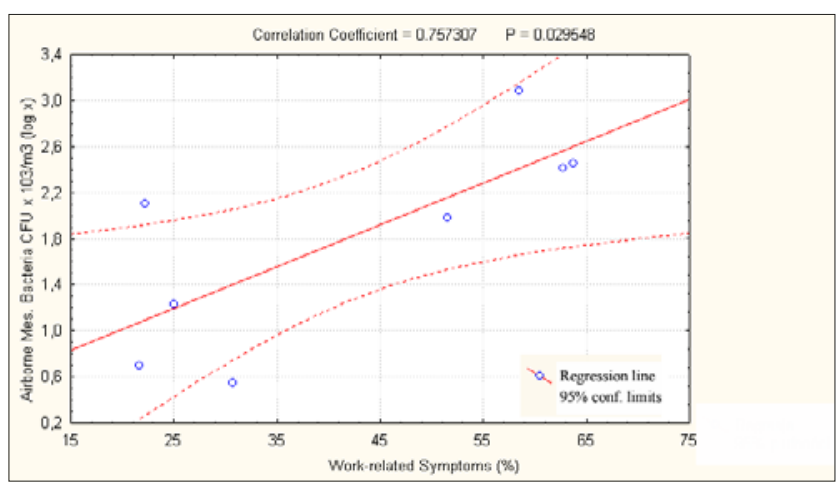

Figure 2. Correlation between concentration of total airborne culturable mesophilic bacteria $\left(\mathrm{CFU} \times 10^{3} / \mathrm{m}^{3}, \log _{10} \mathrm{x}\right.$ ) and frequency of work-related symptoms in exposed agricultural workers

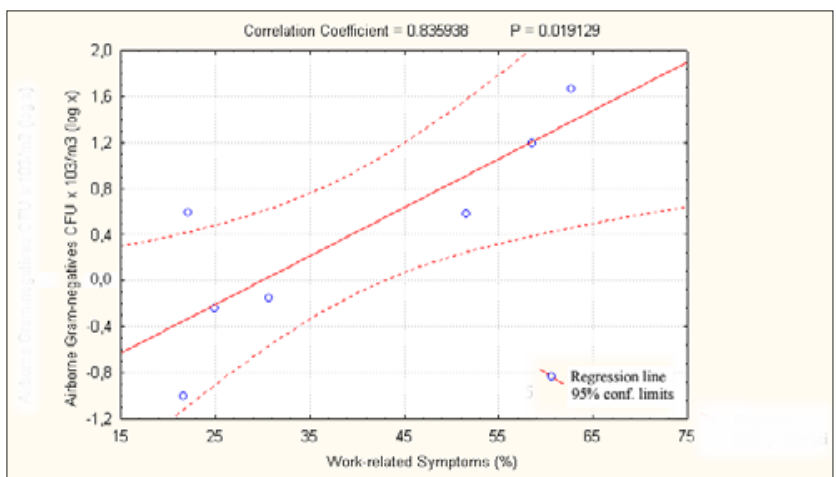

Figure 3. Correlation between concentration of total airborne culturable Gram negative bacteria $\left(\mathrm{CFU} \times 10^{3} / \mathrm{m}^{3}, \log _{10} \mathrm{x}\right)$ and frequency of work-related symptoms in exposed agricultural workers

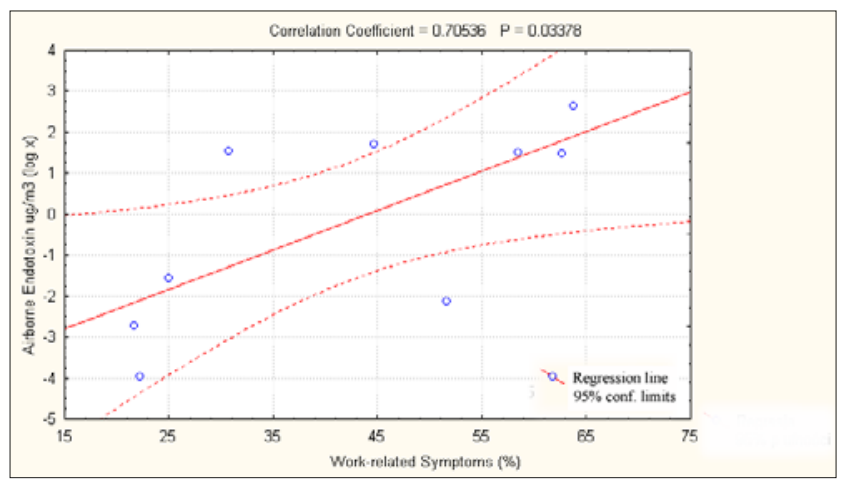

Figure 4. Correlation between concentration of total airborne endotoxins $\left(\mu \mathrm{g} / \mathrm{m}^{3}\right.$, $\log _{10} x$ ) and frequency of work-related symptoms in exposed agricultural workers

culturable fungi in the range of $2.1-77.9 \times 10^{3} \mathrm{CFU} / \mathrm{m}^{3}$, and the airborne bacterial endotoxins in the range of $0.00925-$ $429.55 \mu \mathrm{g} / \mathrm{m}^{3}$. The frequency of work-related symptoms ranged between $21.7-63.8 \%$. Statistically significant correlations were found between the occurrence of workrelated symptoms and the concentrations of total airborne microorganisms $(\mathrm{R}=0.748555 ; \mathrm{P}=0.020317)$ (Fig. 1), mesophilic bacteria ( $\mathrm{R}=0.7573 ; \mathrm{P}=0.029548)$ (Fig. 2), Gram-negative bacteria $(\mathrm{R}=0.835938 ; \mathrm{P}=0.019129)$ (Fig. 3$)$, and endotoxins $(\mathrm{R}=0.705356 ; \mathrm{P}=0.03378$ ) (Fig. 4). The correlations between the concentrations of thermophilic actinomycetes and fungi on one side and frequency of work-related symptoms on the other side did not attain the threshold of significance $(\mathrm{P}=0.087049$ and $\mathrm{P}=0.062963$, respectively).

\section{DISCUSSION}

Until recently, bacterial endotoxin has been the best characterized microbial contaminant of the air in the agricultural working environment. This lipopolysaccharide occurring in the outermost layer of the cell membrane of Gram-negative bacteria is released in huge amounts into the air and dust in the form of vesicular nanoparticles measuring on average $50 \mathrm{~nm}$ [42]. Endotoxin nanoparticles are massively inhaled by exposed workers and penetrate into the deep parts of the lungs, causing chest tightness, fever, and other symptoms typical for organic dust toxic syndrome. Pantoea agglomerans (synonyms: Enterobacter agglomerans, Erwinia herbicola), a common Gram-negative 
bacterium of plant origin, has been identified as a main source of extremely potent endotoxin and allergens which are present in grain dust, cotton dust and other dusts occurring in the agricultural and industrial working environments $[2,3,43,44,45]$. A significant relationship between the concentration of endotoxin in the air and occurrence of work-related symptoms and/or decline in lung function was found in various occupational environments, such as swine production [46], poultry industry [47], animal feed industry [48], grain handling [48, 49, 50], textile industry [51], household waste recycling [52], and wastewater treatment [53]. Interestingly, occupational endotoxin exposure increases the risk for non-allergic diseases, such as organic dust toxic syndrome or chronic bronchitis, but may have a protective effect on allergic sensitization [54].

Nevertheless, bioaerosol that occurs in the various occupational environments represents a rich mosaic of bacteria and fungi, and its adverse effects are not limited to endotoxins, having been largely due to bacterial and fungal allergens, and non-specific harmful substances such as peptidoglycans, $(1 \rightarrow 3)-\beta$-D-glucans, and mycotoxins [21]. Accordingly, some researchers paid attention also to the bioaerosol components other than endotoxin. Thus, Erman et al. [12] proved a significant relationship between the concentrations of total microorganisms in the air of animal houses and the occurrence of respiratory disorders in the exposed breeders. Eduard et al. [55] found in Norwegian farmers, an exposure-response associations between the concentrations of airborne fungal spores and endotoxin and acute work-related symptoms. Melbostad et al. [56] recorded among sewage workers a significant association between levels of airborne bacteria and such symptoms, but not between levels of airborne endotoxin and symptoms. Similarly, Sprince et al. [57] found in machine operators an exposure-response relationship between the concentrations of airborne bacteria and fungi and occurrence of respiratory symptoms. The relationship between airborne endotoxin and such symptoms was also not confirmed.

The studies on bioaerosol and its effects on exposed agricultural workers subjected to meta-analysis in the present work cover a wide spectrum of farm facilities typical for Polish agriculture. They revealed a high degree of exposure to the total airborne microorganisms, mesophilic bacteria and endotoxins which at the most facilities exceeded the proposed allowable concentrations, and lower degrees of exposure to airborne Gram-negative bacteria, airborne thermophilic actinomycetes and airborne fungi which mostly did not exceed the proposed allowable concentrations $[12,14]$. The significant exposure-response relationship found in the presented study between concentration of airborne endotoxins in a wide variety of agricultural settings and occurrence of work-related symptoms in exposed workers confirms the role of endotoxin as an important adverse factor affecting health of the farmers. Nevertheless, similar significant relationships were found also in the case of total airborne microorganisms, total airborne mesophilic bacteria and airborne Gram-negative bacteria, indicating the harmful effects of these factors on the exposed population, and the need for their measurement for the most comprehensive assessment possible of the occupational risk.

In conclusion, the results of the presented study confirm the harmful health effects of the total airborne microorganisms, mesophilic bacteria, Gram-negative bacteria, and bacterial endotoxins on the occupationally-exposed agricultural workers, and indicate the need for the establishment of internationally recognized occupational exposure limits for these microbial agents.

\section{REFERENCES}

1. Pepys J, Jenkins PA, Festenstein GN, Gregory PH, Lacey ME, Skinner FA. Farmer's lung: thermophilic actinomycetes as a source of "farmer's lung hay" antigen. Lancet. 1963; II: 607-611.

2. Dutkiewicz J. Exposure to dust-borne bacteria in agriculture I. Environmental studies. Arch Environ Health. 1978; 33: 250-259.

3. Dutkiewicz J. Exposure to dust-borne bacteria in agriculture. II. Immunological survey. Arch Environ Health. 1978; 33: 260-270.

4. Dutkiewicz J. Bacteria and fungi in organic dust as potential health hazard. In: Midtgård U, Poulsen OM (ed.). International Meeting "Waste Collection and Recycling - Bioaerosol Exposure and Health Problems", 13-14 September 1996, Køge, Denmark. Ann Agric Environ Med. 1997; 4: 11-16.

5. Lacey J, Crook B. Review: Fungal and actinomycete spores as pollutants of the workplace and occupational allergens. Ann Occup Hyg. 1988; 32: 515-533.

6 . Rylander R. The role of endotoxin for reactions after exposure to cotton dust. Am J Ind Med. 1987; 12: 687-697.

7. Rylander R. Organic dusts - from knowledge to prevention. Scand J Work Environ Health. 1994; 20: 116-122.

8. Rylander R, Jacobs RR (eds). Organic Dusts. Exposure, Effects and Prevention. CRC Press, Boca Raton, Florida, 1994.

9. Lacey J, Dutkiewicz J. Bioaerosols and occupational lung disease. J Aerosol Sci. 1994, 25: 1371-1404.

10. Górny RL, Reponen T, Willeke K, Schmechel D, Robine E, Boissier M, Grinshpun SA. Fungal fragments as indoor air contaminants. Appl Environ Microbiol. 2002; 68: 3522-3531.

11. Mackiewicz B. Effects of Organic Dust on Respiratory System Environmental and Clinical Studies. Lublin, Medical University in Lublin, 2013.pp.145 (in Polish).

12. Erman MI, Eglite EM, Olefir AI, Kalinina LN. Aerogenic microflora in animal husbandry and poultry breeding areas, criteria of its harmful effect and hygienic regulations. Gig Truda Prof Zabol. 1989; 4: 19-22 (in Russian).

13. Dutkiewicz J, Górny RL. Biological factors hazardous to human health: classification and criteria of exposure assessment. Med Pr. 2002; 53: 29-39 (in Polish).

14. Górny RL, Dutkiewicz J. Bacterial and fungal aerosols in indoor environment in Central and Eastern European countries. Ann Agric Environ Med. 2002; 9: 17-23.

15. Górny RL. Biological harmful factors: norms, recommendations and proposals of threshold limits values. Podstawy i Metody Oceny Środowiska Pracy. 2004; 3(41): 17-39 (in Polish).

16. Górny RL, Cyprowski M, Ławniczek-Wałczyk A, Gołofit-Szymczak M, Zapór L. Biohazards in the indor environment - a role for threshold limit values in exposure assessment. In: Management of Indoor Air Quality, Leiden, The Netherlands. CRC Press/ Balkema, 2011.pp.1-26.

17. Skowroń J, Górny RL. Harmful biological agents. In: Międzyresortowa Komisja ds. Najwyższych Dopuszczalnych Stężeń i Natężeń Czynników Szkodliwych dla Zdrowia w Środowisku Pracy. Warsaw, Centralny Instytut Ochrony Pracy - PIB. $9^{\text {th }}$ ed. 2014.pp.181-191 (in Polish).

18. Brandys RC, Brandys GM. Worldwide Exposure Standards for Mold and Bacteria - Historical and Current Perspectives. $9^{\text {th }}$ ed. Occupational \& Environmental Health Consulting Services Publications, Inc., Hinsdale, Illinois 2011.

19. Health Council of the Netherlands. Endotoxins. Health-based Recommended Occupational Exposure Limit. Publication no. 2010/04OSH. The Hague, Health Council of the Netherlands, 2010.

20. Rylander R, Donham KJ, Peterson Y (eds.). Health Effects of Organic Dusts in the Farm Environment. Proceedings of an International Workshop held in Skokloster, Sweden, April 23-25, 1985. Am J. Ind Med. 1986; 10(3): 193-340.

21. Rylander R, Peterson Y (eds.). Causative Agents for Organic Dust Related Disease. Proceedings of an International Workshop held in Skokloster, Sweden, April 6-9, 1992. Am J Ind Med. 1994; 25(1): 1-146.

22. Cox CS, Wathes CM (eds.). Bioaerosols Handbook. Boca Raton, FL, CRC Press, 1995.

23. Dutkiewicz J, Krysińska-Traczyk E, Skórska C, Sitkowska J, Prażmo Z, Urbanowicz B. Exposure of agricultural workers to airborne microorganisms and endotoxin during handling of various vegetable products. Aerobiologia 2000; 16: 193-198. 
24. Krysińska-Traczyk E, Dutkiewicz J, Skórska C, Prażmo Z, Cisak E, Sitkowska J, Cholewa G. Occupational exposure of farmers to bioaerosols present in thyme dust. Med Og. 1999; 5: 186-193 (in Polish).

25. Skórska C, Sitkowska J, Krysińska-Traczyk E, Cholewa G, Dutkiewicz J. Exposure to airborne microorganisms, dust and endotoxin during processing of valerian roots on farms. Ann Agric Environ Med. 2005; 12: $119-126$.

26. Krysińska-Traczyk E, Skórska C, Prażmo Z, Sitkowska J, Cholewa G, Dutkiewicz J. Exposure to airborne microorganisms, dust and endotoxin during flax scutching on farms. Ann Agric Environ Med. 2004; 11: 309-317.

27. Góra A, Skórska C, Sitkowska J, Prażmo Z, Krysińska-Traczyk E, Urbanowicz B, Dutkiewicz J. Exposure of hop growers to bioaerosols. Ann Agric Environ Med. 2004, 11: 129-138.

28. Dutkiewicz J, Pomorski ZJH, Sitkowska J, Krysińska-Traczyk E, Skórska C, Prażmo Z, Cholewa G, Wójtowicz H. Airborne microorganisms and endotoxin in animal houses. Grana 1994; 33: 85-90.

29. Chmielowiec-Korzeniowska A, Tymczyna L, Skórska C, Sitkowska J, Cholewa G, Dutkiewicz J. Efficacy of a novel biofilter in hatchery sanitation: I. Removal of airborne bacteria, dust and endotoxin. Ann Agric Environ Med. 2007; 14: 141-150.

30. Skórska C, Mackiewicz B, Dutkiewicz J, Krysińska-Traczyk E, Milanowski J, Feltovich H, Lange J, Thorne PS. Effects of exposure to grain dust in Polish farmers: work-related symptoms and immunologic response to microbial antigens associated with dust. Ann Agric Environ Med. 1998; 5: 147-153.

31. Golec M, Skórska C, Mackiewicz B, Dutkiewicz J. Health effects of exposure to thyme dust in a group of thyme growing farmers. Annales UMCS Sectio D. 2003; 58: 195-203.

32. Skórska C, Golec M, Mackiewicz B, Góra A, Dutkiewicz J. Health effects of exposure to herb dust in valerian growing farmers. Ann Agric Environ Med. 2005; 12: 247-252.

33. Skórska C, Mackiewicz B, Dutkiewicz J. Effects of exposure to flax dust in Polish farmers: work-related symptoms and immunologic response to microbial antigens associated with dust. Ann Agric Environ Med. 2000; 7: 111-118.

34. Skórska C, Mackiewicz B, Góra A, Golec M, Dutkiewicz J. Health effects of exposure to inhalation of organic dust in hop farmers. Annales UMCS Sectio D. 2003, 58: 459-465.

35. Mackiewicz B, Milanowski J, Prażmo Z, Dutkiewicz J. Clinical assessment of the respiratory tract in the workers of animal farms. Pneumonol Alergol Pol. 1998; 66(Supl. 2): 89 (in Polish).

36. Mackiewicz B. Study on exposure of pig farm workers to bioaerosols, immunologic reactivity and health effects. Ann Agric Environ Med. 1998; 5: 147-153

37. Mackiewicz B, Prażmo Z, Milanowski J, Dutkiewicz J, Fąfrowicz B. Exposure to organic dust and microorganisms as a factor affecting respiratory function of the workers of purebred horse farms. Pneumonol Alergol Pol. 1996; 64(Suppl. 1): 19-24 (in Polish).

38. Skórska C, Mackiewicz B, Golec M, Cholewa G, ChmielowiecKorzeniowska A, Dutkiewicz J. Health effects of exposure to organic dust in workers of a modern hatchery. Ann Agric Environ Med. 2007; 14: $341-345$

39. Dutkiewicz J, Kwapiszewski C. New device for study of the microbiological contamination of air. Ochrona Powietrza. 1975; 9(2): 37-42 (in Polish)

40. American Thoracic Society Statement. Snowbird workshop on standardization of spirometry. Am Rev Respir Dis. 1979; 119: 831-838.
41. Dutkiewicz J, Mackiewicz B. Questionnaire evaluating organic dust exposure and the organic dust-related symptoms. In: Dutkiewicz J, Skórska C, Mackiewicz B, Cholewa G. Prevention of the Diseases Caused by Organic Dusts in Agriculture and Food Industry, 85-88. Lublin, Institute of Rural Health, 2000 (in Polish).

42. Dutkiewicz J, Tucker J, Burrell R, Olenchock SA, Schwegler-Berry D, Keller III GE, Ochalska B, Kaczmarski F, Skórska C. Ultrastructure of the endotoxin produced by Gram-negative bacteria associated with organic dusts. System Appl Microbiol. 1992; 15: 474-485.

43. Dutkiewicz J. Studies on endotoxins of Erwinia herbicola and their biological activity. Zbl Bakt Hyg I Abt Orig. A 1976; 236: 487-508.

44. Rylander R, Lundholm M. Bacterial contamination of cotton and cotton dust and effects on the lung. Br J Ind Med. 1978; 35: 204-207.

45. Lemieszek M, Chilosi M, Golec M, Skórska C, Huaux F, Yakoub Y, Pastena C, Daniele I, Cholewa G, Sitkowska J, Lisowska W, Zwoliński J, Milanowski J, Mackiewicz B, Góra A, Dutkiewicz J. Mouse model of hypersensitivity pneumonitis after inhalation exposure to different microbial antigens associated with organic dusts. Ann Agric Environ Med. 2011; 18: 159-168.

46. Reynolds SJ, Donham KJ, Whitten P, Merchant JA, Burmeister LF, Popendorf WJ. Longitudinal evaluation of dose-response relationships for environmental exposures and pulmonary function in swine production workers. Am J Ind Med. 1996; 29(1): 33-40.

47. Donham KJ, Cumro D, Reynolds SJ, Merchant JA. Dose-response relationships between occupational aerosol exposures and cross-shift declines of lung function in poultry workers: recommendations for exposure limits. J Occup Environ Med. 2000; 42(3): 260-269.

48. Post W, Heederik D, Houba R. Decline in lung function related to exposure and selection processes among workers in the grain processing and animal feed industry. Occup Environ Med. 1998; 55(5): 349-355.

49. Schwartz DA, Thorne PS, Yagla SJ, Burmeister LF, Olenchock SA, Watt JL, Quinn TJ. The role of endotoxin in grain dust-induced lung disease. Am J Respir Crit Care Med. 1995; 152(2): 603-608.

50. Viet SM, Buchan R, Stallones L. Acute respiratory effects and endotoxin exposure during wheat harvest in Northeastern Colorado. Appl Occup Environ Hyg. 2001; 16(6): 685-697.

51. Mukherjee AK, Chattopadhyay BP, Bhattacharya SK, Saiyed HN. Airborne endotoxin and its relationship to pulmonary function among workers in an Indian jute mill. Arch Environ Health. 2004; 59(4): 202-208.

52. Gladding T, Thorn J, Stott D. Organic dust exposure and work-related effects among recycling workers. Am J Ind Med. 2003; 43(6): 584-591.

53. Smit LA, Spaan S, Heederik D. Endotoxin exposure and symptoms in wastewater treatment workers. Am J Ind Med. 2005; 48(1): 30-39.

54. Basinas I, Schlünssen V, Heederik D, Sigsgaard T, Smit LA, Samadi S, Omland O, Hjort C, Madsen AM, Skov S, Wouters IM. Sensitisation to common allergens and respiratory symptoms in endotoxin exposed workers: a pooled analysis. Occup Environ Med. 2012; 69(2): 99-106.

55. Eduard W, Douwes J, Mehl R, Heederik D, Melbostad E. Short term exposure to airborne microbial agents during farm work: exposureresponse relations with eye and respiratory symptoms. Occup Environ Med. 2001; 58(2): 113-118.

56. Melbostad E, Eduard W, Skogstad A, Sandven P, Lassen J, Søstrand P, Heldal K. Exposure to bacterial aerosols and work-related symptoms in sewage workers. Am J Ind Med. 1994; 25(1): 59-63.

57. Sprince NL, Thorne PS, Popendorf W, Zwerling C, Miller ER, DeKoster JA. Respiratory symptoms and lung function abnormalities among machine operators in automobile production. Am J Ind Med. 1997; 31(4): 403-413. 